\title{
Short Term Efficacy of Laparoscopy Assisted vs Open Gastrectomy with D2 Lymph Node Dissection for Advanced Gastric Cancer
}

\section{İleri evre mide kanserinde laparoskopi yardımlı ve açık gastrektomi ile birlikte uygulanan D2 diseksiyonun erken dönem etkinliği}

\author{
Bulent Aksel, Niyazi Karaman, Lutfi Dogan, Bahadir Ondes, Mehmet Ali Gulcelik \\ ${ }^{1}$ Department of General Surgery, Ankara Oncology Training and Research Hospital, Ankara, Turkey \\ ${ }^{2}$ Department of General Surgery, Gülhane Training And Research Hospital, Istnabul, Turkey \\ ${ }^{3}$ Department Of General Surgery, Van Ercis State Hospital, Van, Turkey
}

\begin{abstract}
ÖZET
GİRIŞ ve AMAÇ: Erken evre dişındaki mide kanserinin en etkili küratif tedavisi radikal gastrektomi ile birlikte D2 diseksiyon uygulanmasıdır. Bu konuda bir diğer teknik alternatif ise laparoskopi yardımlı gastrektomidir. Her ne kadar minimal ivaziv işlem olarak laparoskopik cerrahinin avantajları iyi bilinse de, bu işlem radikal onkolojik prensiplere ulaşabilmesi ve sonuçların ortaya konması açısından değerlendirilmelidir.

YÖNTEM ve GEREÇLER: Evre IIA ve üzeri mide kanserli hastalarda laparoskopi yardımlı (19 hasta) ve açık cerrahinin (23 hasta) erken sonuçları değerlendirilmiştir.

BULGULAR: Laparoskopi yardımlı grupta, hem kanama hem de postoperatif dönmede analjezik ihtiyacı belirgin olarak daha az iken (sırasıyla, 166.9 $\pm 66.5 \mathrm{~mL}$ 'ye karşılık $264.3 \pm 91.3 \mathrm{~mL}, 6.4 \pm 1.5$ 'ye karş1lık $9.04 \pm 1.7$ kez), ameliyat süresi daha uzun olarak bulundu (183 \pm 31.1 dakikaya karşılık $155 \pm 29.5$ dakika). Cerrahi sınırlar ve çıkarılan lenf nodu sayısı açısından fark yoktu. Açık cerrahi grubunda akciğer komplikasyonları daha sıktı.

TARTIŞMA ve SONUÇ: Laparoskopi yardımlı radikal gastrektomi ile birlikte D2 diseksiyon erken evre dişı mide kanserlerinde de etkin ve güvenilir bir cerrahi uygulamadır. Erken postoperatif iyileşme döneminde bazı üstünlükleri olduğu düşünülmüştür.
\end{abstract}

Anahtar Kelimeler: laparoskopi yardımlı gastrektomi, mide kanseri, lenf nodu diseksiyonu

\begin{abstract}
INTRODUCTION: The most effective curative treatment for gastric cancer other than early stage is radical gastrectomy with D2 lymph node dissection. Laparoscopy assisted gastrectomy is one of the technique alternatives on this issue. Although the advantages of laparoscopic surgery as a minimal invasive procedure is well known, it should be evaluated for the reach of radical oncological principles and the results should be revealed.
\end{abstract}

METHODS: The early results of patients with clinical stage IIA and over gastric carcinoma that had been operated with laparoscopy assisted (19 patients) and open surgery (23 patients) were evaluated.

RESULTS: In laparoscopy assisted group, both the bleeding and the need for analgesics in postoperative period were significantly less $(166.9 \pm 66.5 \mathrm{ml}$ vs $264.3 \pm 91.3 \mathrm{ml}, 6.4 \pm 1.5$ vs $9.04 \pm 1.7$, times respectively) but the time needed to complete surgery was longer $(183 \pm 31.1 \mathrm{~min}$ vs $155 \pm 29.5 \mathrm{~min})$. There was no difference in the numbers of lymph nodes removed and surgical resection margins. The pulmonary complications were more frequent in open surgery group.

DISCUSSION and CONCLUSION: Laparoscopy assisted radical gastrectomy with D2 lymph node dissection is an effective and safe surgical technique for gastric cancers other than early stage. It is thought to have some superiorities in early postoperative healing.

Keywords: laparoscopy assisted gastrectomy, gastric cancer, lymph node dissection.

\section{INTRODUCTION}

Laparoscopic gastrectomies (total/assisted) were accepted as an important alternative to open surgery in the surgical treatment of gastric cancer for more than ten years $(1,2)$.
The increased popularity of this technique was started with early stage gastric cancer and distal subtotal gastrectomy. The studies about the safety of laparoscopic procedures, the oncological results and advantageous aspects are promising $(3,4)$. Although the rates of early gastric cancer is increasing, the vast majority 
of the gastric canceres are still diagnosed in advanced stages (5). As the suspicions for the lymph node dissection technique and for early and late results still exist, the widespread use of radical laparoscopic gastrectomies for cancers other than early stages has not been possible $(6,7)$. On the other hand, with the implementation of more complex laparoscopic procedures and advances in auxiliary equipment, the numbers of laparoscopic total gastrectomies have been started to increase (8).

The most important treatment modality in curative treatment of gastric cancer is surgical resection and one of the most important factors for survival advantage of the surgery is lymph node dissection (9). Although the advantages of laparoscopic surgery as a minimal invasive procedure is well known, it should be evaluated for the reach of same radical oncological principles of open surgery.

In this paper, the early results of laparoscopy assisted radical gastrectomies with D2 dissection in gastric cancer other than early stages were presented.

\section{PATIENTS and METHODS}

The early results of patients with clinical stage IIA and over gastric carcinoma that had been operated with radical gastrectomy in between February 2013 and February 2014 by the same surgical team were evaluated. The desicion about laparoscopic and open surgery was made with the patients and written informed consent was obtained. In patients decided to be operated with laparoscopic surgery, the upper gastrointestinal endoscopy was repeated by the surgical team. The patients with conversion to open surgery and treated with neoadjuvant chemotherapy were excluded. The age, gender, American Society of Anesthesiologists (ASA) scores, tumor localisation, clinical stage, Body Mass Index (BMI), comorbidies (cardiac, respiratory, diabetes mellitus), smoking habits, the amount of intraoperative bleeding and complications, operation time, the need for analgesics in postoperative period, the time needed for passing of first flatus, morbidity and mortalities were recorded.

The numbers of total and metastatic lymph nodes removed, the distance to proximal and distal resection margins were also recorded with the examination of pathology reports. The staging system of American Joint Commission on Cancer (AJCC) 2010 was used for TNM staging.

The patient were called for control examination in 30 and 60 days of surgery. The surgical sites were checked and the patients with the complaint of abdominal pain were examined with abdominal computed tomography (CT). The patients with the complaint of difficulty in swallowing were examined with upper GI endoscopy.

The lymph node stations of perigastric and $7,8 \mathrm{a}, 9,10,11 \mathrm{p}, 11 \mathrm{~d}$ and $12 \mathrm{a}$ were included to the spesimen in patients operated with laparoscopy assisted subtotal gastrectomy. The spesimen was extracted through the extended left lateral $5 \mathrm{~mm}$ port site. Roux en $\mathrm{Y}$ anastomosis was performed with hand sewn sutures. In total gastrectomy cases, esofagojejunostomy was performed intracorporally with the help of OrVil ${ }^{\mathrm{TM}}$ (Covidien, Mansfield, MA, USA). Jejunojejunal anastomosis was performed extracorporally through the extended left lateral $5 \mathrm{~mm}$ port site.

Statistical analysis was performed using SPSS 18.0 (SPSS Inc., Chicago, IL, United States). Continuous data are presented as mean $\pm \mathrm{SD}$, and were analyzed using Student's $t$ test. Categorical data are presented as proportions, and were analyzed using the $\chi 2$ test. $P<0.05$ was considered statistically significant.

\section{RESULTS}

Thirteen subtotal and 6 total gastrectomies were performed among 19 patients operated with laparoscopy assisted gastrectomies (LAG). Thirteen subtotal and 10 total gastrectomies were performed among 23 patients operated with open gastrectomies (OG).

The median age of the patients was $63.4 \pm 12.9$ and the median BMI was $26 \pm 2.3$. There was no difference between groups with respect to the age, gender, ASA scores, tumor localisation, BMI, comorbidies (cardiac, respiratory, diabetes mellitus), smoking habits. The general characteristics of patients were summarised in (Table1).

In laparoscopy assisted group, both the bleeding and the need for analgesics in 
postoperative period were significantly less $(166.9 \pm 66.5 \mathrm{ml}$ vs $264.3 \pm 91.3 \mathrm{ml}, 6.4 \pm 1.5$ vs $9.04 \pm 1.7$, times respectively). Whereas, the time needed to complete surgery in LAG group was longer ( $183 \pm 31.1 \mathrm{~min}$ vs $155 \pm 29.5 \mathrm{~min}$ ). Although, the patients in LAG group passed flatus 8 hours earlier and discharged from the hospital 2.5 days earlier than OG group, this difference was not statistically significant. While 23.7 \pm 7.3 lymph nodes were dissected in LAG group, this number was $25.8 \pm 7.7$ in $\mathrm{OG}$ group, and this difference was not significant. When the pathology reports were examined for the surgical resection margins, more than $4 \mathrm{~cm}$ in proximal and $5 \mathrm{~cm}$ in distal margins was achieved in both groups (Table-2).

One surgical site infection (SSI) in early postoperative period and delayed anastomotic stenosis and one bleeding at port site was seen in LAG. Mortality was recorded in one patient due to delayed duodenal leakage at the first month of the surgery. Pulmonary infection in 3 patients, enterocutaneous fistula in 2 patients and SSI in 2 patients were recorded in OG group. There was no mortality in this group. Pulmonary infections were more frequent in OG group and this difference was statistically significant (Table-3).

Table1. Patients characteristics.

\begin{tabular}{|c|c|c|c|c|}
\hline & $\begin{array}{l}\text { LAG } \\
(\mathrm{n}: 19)\end{array}$ & OG (n:23) & $\begin{array}{c}\mathrm{p} \\
\text { value }\end{array}$ \\
\hline \multicolumn{2}{|l|}{ Age } & $59.4 \pm 7.4$ & $62.08 \pm 8.6$ & 0.06 \\
\hline \multirow[t]{2}{*}{ Gender } & Male & $10(52 \%)$ & $14(60 \%)$ & \multirow[t]{2}{*}{0.4} \\
\hline & Female & $9(48 \%)$ & $9(40 \%)$ & \\
\hline \multirow[t]{2}{*}{ ASA score } & 2 & $10(52 \%)$ & $10(44 \%)$ & \multirow[b]{2}{*}{0.2} \\
\hline & 3 & $9(48 \%)$ & $13(56 \%)$ & \\
\hline \multicolumn{2}{|l|}{ BMI } & $25.9 \pm 2.8$ & $25.3 \pm 1.7$ & 0.3 \\
\hline \multicolumn{2}{|l|}{ Smoking(+) } & $8(42 \%)$ & $\begin{array}{c}11 \\
(47.8 \%) \\
\end{array}$ & 0.3 \\
\hline \multicolumn{2}{|c|}{$\begin{array}{l}\text { Cardiac co- } \\
\text { morbidities (+) }\end{array}$} & $4(21 \%)$ & $5(21 \%)$ & 0.8 \\
\hline \multicolumn{2}{|c|}{$\begin{array}{l}\text { Respiratory co- } \\
\text { morbidities }(+)\end{array}$} & $\begin{array}{c}2 \\
(10.5 \%) \\
\end{array}$ & $4(17 \%)$ & 0.2 \\
\hline \multicolumn{2}{|l|}{$\mathrm{DM}(+)$} & $\begin{array}{c}3 \\
(15.7 \%)\end{array}$ & $5(21.7 \%)$ & 0.2 \\
\hline \multirow{4}{*}{$\begin{array}{l}\text { Tumor } \\
\text { localisation }\end{array}$} & Antrum & $7(37 \%)$ & $7(30 \%)$ & \multirow{4}{*}{0.1} \\
\hline & Corpus & $8(42 \%)$ & $11(48 \%)$ & \\
\hline & Cardia & $4(21 \%)$ & $4(17.3 \%)$ & \\
\hline & Pyloris & 0 & $1(4.3 \%)$ & \\
\hline
\end{tabular}

LAG: Laparoscopy assisted gastrectomy, OG: Open gastrectomy, ASA: American Society of Anestesiologists, BMI: Body Mass Index, DM: Diabetes Mellitus
Table 2. Surgical outcomes between laparoscopi assisted and open radical gastrectomy groups

\begin{tabular}{|c|c|c|c|c|}
\hline & $\begin{array}{l}\text { LAG } \\
(\mathrm{n}: 19)\end{array}$ & OG (n:23) & $\begin{array}{c}\mathrm{p} \\
\text { valu } \\
\mathrm{e}\end{array}$ \\
\hline \multicolumn{2}{|c|}{ Operation time (min) } & $183 \pm 31.1$ & $155 \pm 29.5$ & 0.03 \\
\hline \multicolumn{2}{|c|}{ Bleeding (ml) } & $\begin{array}{c}166.9 \pm 66 . \\
5\end{array}$ & $\begin{array}{c}264.3 \pm 91 . \\
3\end{array}$ & 0.01 \\
\hline \multicolumn{2}{|c|}{$\begin{array}{l}\text { Need for analgesics } \\
\text { (dosage) }\end{array}$} & $6.4 \pm 1.5$ & $9.04 \pm 1.7$ & 0.01 \\
\hline \multicolumn{2}{|l|}{ Flatus (hr) } & $60.8 \pm 10.2$ & $67 \pm 12.5$ & 0.07 \\
\hline \multicolumn{2}{|c|}{ Hospitalization (day) } & $7.8 \pm 2.4$ & $10.5 \pm 6.4$ & 0.07 \\
\hline \multicolumn{2}{|c|}{ Lymph nodes removed } & $23.7 \pm 7.3$ & $25.8 \pm 7.7$ & 0.3 \\
\hline \multirow{2}{*}{$\begin{array}{l}\text { Resection } \\
\text { margins(c } \\
\text { m) }\end{array}$} & proximal & $4.5 \pm 2.3$ & $4.8 \pm 3.1$ & 0.7 \\
\hline & distal & $6.02 \pm 3.5$ & $5.1 \pm 4$ & 0.4 \\
\hline
\end{tabular}

LAG: Laparoscopi assisted gastrectomy, OG: Open gastrectomy

Table 3 Postoperative complications between laparoscopic and open radical gastrectomy groups

\begin{tabular}{|l|c|c|c|}
\hline & $\begin{array}{c}\text { LAG } \\
(\mathrm{n}: 19)\end{array}$ & $\begin{array}{c}\text { OG } \\
(\mathrm{n}: 23)\end{array}$ & $\begin{array}{c}\mathrm{p} \\
\text { value }\end{array}$ \\
\hline $\begin{array}{l}\text { Pulmonary } \\
\text { infection }\end{array}$ & 0 & $3(13 \%)$ & 0.03 \\
\hline $\begin{array}{l}\text { Anastomotic } \\
\text { leakage/stump } \\
\text { fistula }\end{array}$ & $1(5.2 \%)$ & $2(8.6 \%)$ & 0.7 \\
\hline Bleeding & $1(5.2 \%)$ & 0 & 0.4 \\
\hline SSI & $1(5.2 \%)$ & $2(8.6 \%)$ & 0.7 \\
\hline $\begin{array}{l}\text { Anastomotic } \\
\text { stenosis }\end{array}$ & $1(5.2 \%)$ & 0 & 0.4 \\
\hline
\end{tabular}

LAG: Laparoscopy assisted gastrectomy, OG: Open gastrectomy, SSI: Surgical site infection

\section{DISCUSSION}

The advantages of laparoscopic surgery are less pain, less blood loss, the fast return of gastrointestinal functions, shorter hospital stay, less restriction in physical activity and better cosmetic results (10). It is thought that the main reason for this advantages is the less inflammatory response to surgical trauma and better glucose tolerance (11). The first laparoscopic gastrectomy studies were started at the end 90's to obtain these advantages in gastric surgery (12). Although, this technique was started to be accepted among surgeons, it was not so easy and fast as in the case of laparoscopic colon surgery (13). Although, the increased experience with the implementation of more complex laparoscopic procedures and advances in auxiliary equipment, increased the interst to laparoscopic gastric surgery, its concordance to radical oncological principles has raised some questions. It was thought that 
the absence of sense of touch might endanger the completeness of lymph node dissection and surgical margins (10). In fact, lymph node dissection is technically much more difficult than laparoscopic colon surgery $(14,15)$. Therefore, the first surgeries were peformed for early stage (T1-2 and N0) gastric cancer cases. The technical superiority of laproscopic surgery without survival disadvantage in the traeatment of early gastric cancer has been demonstrated $(16,179$. But, it is also known that more than $60 \%$ of gastric cancer has been diagnosed in advanced stage (189. The value of D2 dissection had been evaluated fairly well for the treatment of these patients $(19,20)$. The safety of D2 dissection in the treatment of laparoscopic surgical treatment of gastric cancer is an important research subject. There is no randomised controlled study on this subject and the centers dealing with it should present their own results. The implementation of this technique is only possible after adequate experience on gastric and laparoscopic surgery.

In metaanalysis and patient series focusing on early results of laparoscopic surgery in patients with gastric cancer other than early stages, blood loss has been reported to be $100-220 \mathrm{~mL}$ less in laparoscopic surgery. The length of hospital stay is 3-6 days shorter in laparoscopic surgery. The passing of first flatus and the start of oral feeding are earlier and the need for analgesics is less in laparoscopic surgery. On the other hand, the time needed to complete surgery is 40-90 minutes longer in laparoscopic surgery (2127). Our study supports the evidence about the positive effects of laparoscopic surgery on early wound healing.

The probable reasons for less blood loss in laparoscopic surgery might be the better exposure of camera with magnified and angulated views, the smaller sizes of dissecting instruments and the use of advanced technological sealing devices. Besides, the blood loss from skin and muscles encountered during laparotomy is less in laparoscopic surgery. But, the trocar site bleeding seen in one of our patients remind us the importnce of this issue before the completion of surgery. At the same time, less blood loss means less need for transfusion, the decreased risk for hypothermia, volume overload and acute lung injury. Immunomodulatory effects of transfusion might be one of the factors related with decreased morbidity. The decreased surgical trauma results with early return of bowel motility and decreased need for analgesics.

Indeed, laparoscopic gastric surgery is a time consuming procedure. The time increases even more in learning period (28). The experience of surgeon decreases the time needed. The operation times have been shortened with the recent technological advances in laparoscopic instruments. The difference is becoming less especially in subtotal gastrectomy $(29,30)$. But currently, it does not seem to be possible to reach the operation times of open surgery.

When the subject was evaluated in terms of the ongological safety, it was observed that at the beginnig, the numbers of lymph nodes dissected was higher in open surgery. But this occurance was disappeared with time (21). In recent studies, the numbers of lymph nodes dissected are either similar or slight differences with no statistical significance in favor of open surgery was reported (27). In our series median 23.7 \pm 7.3 lymph nodes were dissected in laparoscopic surgery group. There was no statistical difference in numbers of lymph nodes dissected with open surgery. These numbers seem to be sufficient for staging of gastric cancer. The minimum recommended number of lymph nodes for correct staging of gastric cancer is 15 (31). The loss of sense of touch in laparoscopic surgery brings the concern about the safety of resection margins. Intraoperative identification of tumor margins in locally advanced tumors is generally easy. The negative impact of this issue decreased with growing experience in total gastrectomy (32). Besides, the performance of endoscopic procedures by the surgical team is an advantage for the safety of resection margins. There was also no patient in laparoscopic surgery group with less than $2 \mathrm{~cm}$ resection margins in our series. The median proximal and distal resection margins in this group was more than $4 \mathrm{~cm}$.

In our series, although the duration of anesthesia was shorter in open surgery group, the incidence of pulmanory infections were higher. The incidence of pulmanory infection was lower in laparoscopic surgery due to the absence of long incision with the low risk of 
hypoventilation and atelectasis. It was known that the negative effect of laparoscopic surgey on FVC and FEV1 is less than that of open surgery (33). As it was mentioned earlier, the decreased need for transfusion reduces the risk of hypotermia and lung injury due to volume overload. Although it was reported that the risk of surgical site infection in open surgery is higher (34), there was no statistically significant difference between two groups in our series.

In literature, the difference about the anastomotic complications (leak, stenosis) in between open and laparoscopic surgery was not revealed (23). There was no difference in the incidence of anastomotic complications in our series as well. The single mortality in our series was seen in laparoscopic surgery group at one month of surgery and it was due to the late anastomotic leak seen at duodenal stump. There was no inhospital mortality in both groups.

\section{CONCLUSION}

As a result, laparoscopy assisted gastric surgery with D2 dissection in gastric cancers other than early stages is an effective and safe procedure. We believe that laparoscopy assisted gastric surgery has some advantages in the early postoperative healing period without impairing oncologic results.

Conflict of interest: The authors declare that they have no conflict of interest

\section{REFERENCES}

1. Ohtani H, Tamamori $Y$, Noguchi $K$, Azuma T, Fujimoto $\mathrm{S}$, Oba $\mathrm{H}$, et al. A meta-analysis of randomized controlled trials that compared laparoscopy-assisted and open distal gastrectomy for early gastric cancer. J Gastrointest Surg. 2010;14:958-64.

2. Qiu J, Pankaj P, Jiang $\mathrm{H}$, Zeng $\mathrm{Y}, \mathrm{Wu} \mathrm{H}$. Laparoscopy versus open distal gastrectomy for advanced gastric cancer: a systematic review and meta-analysis. Surg Laparosc Endosc Percutan Tech. 2013;23:1-7.

3. Jiang L, Yang KH, Guan QL, Cao N, Chen Y, Zhao $\mathrm{P}$, et al. Laparoscopy-assisted gastrectomy versus open gastrectomy for resectable gastric cancer: an update meta-analysis based on randomized controlled trials. Surg Endosc. 2013;27:2466-80.

4. Ding J, Liao GQ, Liu HL, Liu S, Tang JJ. Metaanalysis of laparoscopy-assisted distal gastrectomy with D2 lymph node dissection for gastric cancer. J Surg Oncol. 2012;105:297-303.

5. Li QG, Li P, Tang D, Chen J, Wang DR. Impact of postoperative complications on long-term survival after radical resection for gastric cancer. World $\mathbf{J}$ Gastroenterol 2013; 19: 4060-5.

6. Pugliese R, Maggioni D, Sansonna F, Scandroglio I, Ferrari GC, Di Lernia S, et al. Total and subtotal laparoscopic gastrectomy for adenocarcinoma. Surg Endosc. 2007;21:21-7.

7. Strong VE, Devaud N, Allen PJ, Gonen M, Brennan MF, Coit D. Laparoscopic versus open subtotal gastrectomy for adenocarcinoma: A casecontrol study. Ann Surg Oncol 2009;16:1507-13.

8. Inaba K, Satoh S, Ishida Y, Taniguchi K, Isogaki J, Kanaya S, et al. Overlap method: novel intracorporeal esophagojejunostomy after laparoscopic total gastrectomy. J Am Coll Surg. 2010;211:25-9.

9. Nakajima T. Gastric cancer treatment guidelines in Japan. Gastric Cancer 2002;5:1-5.

10. Shehzad K, Mohiuddin K, Nizami S, Sharma H, Khan IM, Memon B, et al. Current status of minimal Access surgery for gastric cancer. Surg Oncol. 2007; 16:85-98.

11. Kawamura H, Yokota R, Homma S, Kondo Y. Comparison of invasiveness between laparoscopyassisted total gastrectomy and open total gastrectomy. World J Surg. 2009;33:2389-95.

12. Azagra JS, Goergen $M$, DeSimone $P$, Ibañez J. Minimally invasive surgery for gastric cancer. Surg Endosc. 1999;13:351-7.

13. Ibáñez Aguirre FJ, Azagra JS, Erro Azcárate ML, Goergen M, Rico Selas P, Moreno Elola-Olaso A, et al. Laparoscopic gastrectomy for gastric adenocarcinoma. Long-term results. Rev Esp Enferm Dig. 2006;98:491-500.

14. Miura S, Kodera $Y$, Fujiwara M, Ito S, Mochizuki $\mathrm{Y}$, Yamamura $\mathrm{Y}$, et al. Paroscopy-assisted distal gastrectomy with systemic lymph node dissection: a critical reappraisal from the viewpoint of lymph node retrieval. J Am Coll Surg. 2004;198:933-8.

15. Liang Y, Li G, Chen P, Yu J and Zhang C. Laparoscopic versus open gastrectomy for early distal gastric cancer: a meta-analysis. ANZ J Surg. 2011;81:673-80

16. Yakoub D, Athanasiou $T$, Tekkis $P$, Hanna GB. Laparoscopic assisted distal gastrectomy for early gastric cancer: is it an alternative to the open approach? Surg Oncol. 2009;18:322-33.

17. Kim HH, Hyung WJ, Cho GS, Kim MC, Han SU, Kim W, et al. Morbidity and mortality of laparoscopic gastrectomy versus open gastrectomy for gastric cancer: an interim report--a phase III multicenter, prospective, randomized Trial (KLASS Trial). Ann Surg. 2010;251:417-20.

18. Parkin DM. Intemational variation. Oncogene 2004;23:6329-40.

19. Pugliese R, Maggioni D, Sansonna F, Costanzi A, Ferrari GC, Di Lernia S, et al. Subtotal gastrectomy with $\mathrm{D} 2$ dissection by minimally invasive surgery for distal adenocarcinoma of the stomach: results and 5-year survival. Surg Endosc. 2010;24:2594602.

20. Zilberstein B, Mucerino DR, Yagi OK, RibeiroJunior U, Lopasso FP, Bresciani C, et al. Results of 
D2 gastrectomy for gastric cancer: lymph node chain dissection or multiple node resection? Arq Bras Cir Dig. 2012;25:161-64.

21. Memon MA, Khan S, Yunus RM, Barr R, Memon B. Meta-analysis of laparoscopic and open distal gastrectomy for gastric carcinoma. Surg Endosc. 2008;22:1781-9.

22. Huang YL, Lin HG, Yang JW, Jiang FQ, Zhang T, Yang HM, et al. Laparoscopy-assisted versus open gastrectomy with D2 lymph node dissection for advanced gastric cancer: a meta-analysis. Int J Clin Exp Med. 2014;7:1490-9.

23. Xiong JJ, Nunes QM, Huang $\mathrm{W}$, Tan CL, Ke NW, Xie SM, et al. Laparoscopic vs open total gastrectomy for gastric cancer: a meta-analysis. World J Gastroenterol. 2013;19:8114-32.

24. Li HT, Han XP, Su L, Zhu WK, Xu W, Li K, et al. Short-term efficacy of laparoscopy-assisted vs open radical gastrectomy in gastric cancer. World $\mathrm{J}$ Gastrointest Surg. 2014;6:59-64.

25. Martínez-Ramos D, Miralles-Tena JM, Cuesta MA, Escrig-Sos J, Van der Peet D,Hoashi JS, et al. Laparoscopy versus open surgery for advanced and resectable gastric cancer: a meta-analysis. Rev Esp Enferm Dig. 2011;103:133-41.

26. Haverkamp L, Weijs TJ, van der Sluis PC, van der Tweel I, Ruurda JP, van Hillegersberg R. Laparoscopic total gastrectomy versus open total gastrectomy for cancer: a systematic review and meta-analysis. Surg Endosc. 2013;27:1509-20.

27. Wei HB, Wei B, Qi CL, Chen TF, Huang Y, Zheng $\mathrm{ZH}$, et al. Laparoscopic versus open gastrectomy with D2 lymph node dissection for gastric cancer: a meta-analysis. Surg Laparosc Endosc Percutan Tech. 2011;21:383-90.
28. Fujiwara M, Kodera Y, Kasai Y, Kanyama Y, Hibi $\mathrm{K}$, Ito $\mathrm{K}$, et al. Laparoscopy- assisted distal gastrectomy with systemic lymph node dissection: a phase II study following the learning curve. J Surg Oncol. 2005;91:26-32.

29. Adachi Y, Shiraishi N, Shiromizu A, Bandoh T, Aramaki M, Kitano S. Laparoscopy assisted Billroth I gastrectomy compared with conventinal open gastrectomy. Arch Surg. 2000;135:806-10.

30. Kunisaki C, Makino H, Kosaka T, Oshima T, Fujii S, Takagawa R, Kimura J, Ono HA, Akiyama H, Taguri M, Morita S, Endo I. Surgical outcomes of laparoscopy-assisted gastrectomy versus open gastrectomy for gastric cancer: a case control study. Surg Endosc 2012; 26: 804-10.

31. Kwon SJ. Evaluation of the 7th UICC TNM Staging System of Gastric Cancer. J Gastric Cancer 2011;11:78-85.

32. Choi YY, An JY, Hyung WJ, Noh SH. Comments to young surgeons concerning laparoscopic spleenpreserving D2 lymph node dissection for advanced gastric cancer on the upper body. Chin J Cancer Res. 2014;26:231-3.

33. McMahon AJ, Baxter JN, Kenney G, O'Dwyer PJ. Ventilatory and blood gas change during laparoscopic and open cholecystectomy. Br J Surg. 1993;80:1252-4.

34. Schwenk W, Bohm B, Muller JM. Postoperative pain and fatigue after laparoscopic or conventional colorectal resections: a prospective randomized trial. Surg Endosc 1998; 12:1131-6. 